\author{
JOURNAL OF INFORMATION \\ SYSTEM AND TECHNOLOGY \\ MANAGEMENT \\ (JISTM) \\ WWW.jistm.com
}

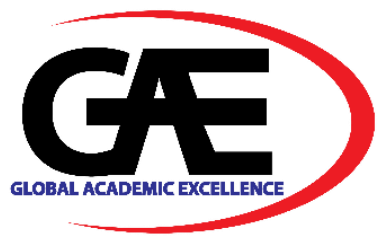

\title{
AN ASSESSMENT OF UMS PRE-UNIVERSITY STUDENTS' READINESS ON ONLINE EXAMINATION
}

\author{
Suriana Lasaraiya ${ }^{1}$, Mohd Azrul Abd Rajak ${ }^{2 *}$, Che Haziqah Che Hussin ${ }^{3}$, Nurliyana Juhan ${ }^{4}$ \\ 1 Preparatory Centre for Science and Technology, Universiti Malaysia Sabah, Malaysia \\ Email: suriana@ums.edu.my \\ 2 Preparatory Centre for Science and Technology, Universiti Malaysia Sabah, Malaysia \\ Email: azrulrajak88@ums.edu.my \\ 3 Preparatory Centre for Science and Technology, Universiti Malaysia Sabah, Malaysia \\ Email: haziqah@ums.edu.my \\ 4 Preparatory Centre for Science and Technology, Universiti Malaysia Sabah, Malaysia \\ Email: liyana87@ums.edu.my \\ Corresponding Author
}

\section{Article Info:}

Article history:

Received date: 11.09 .2021

Revised date: 10.10 .2021

Accepted date: 15.11 .2021

Published date: 30.11 .2021

\section{To cite this document:}

Lasaraiya, S., Rajak, M. A. A., Che Hussin, C. H., \& Juhan, N. (2021). An Assessment Of UMS Pre-University Students' Readiness On Online Examination. Journal of Information System and Technology Management, 6 (23), 147-155.

DOI: $10.35631 /$ JISTM.623013

This work is licensed under $\underline{\text { C BY } 4.0}$ (1) (1)

\begin{abstract}
:
Pandemic COVID-19 has given a significant impact on the education culture whereby online learning has become the main way in teaching and learning activities. In line with the important use of online learning, it is very important to identify whether the students are ready enough for an online class or not. The study on 'An Assessment of UMS Pre-University Students' Readiness on Online Examination' sought to answer the questions about students' readiness on the preferred mode of learning and the student's readiness on an online examination. The respondents of the study were UMS Pre-University students who enrolled in the Foundation in Science program (AUMS) in the year 2020. Specifically, there was 105 male, and 153 female students were included in the study. Through Google form online survey, the questionnaires were sent through their email and WhatsApp group. Then, the data were gathered, collected, and analysed. Descriptive statistics analysis and item level mean related to students' internet connectivity is provided in the form of percentage, mean and standard deviations. The study reveals that AUMS students' internet connectivity was moderately ready for their online examinations, as it depends mainly on their location. If the students are staying in an urban areas, then their internet connections should be good and vice versa. This study also reveals that problems in Wi-Fi connection are the main concern of students' accessibility to online learning.
\end{abstract}




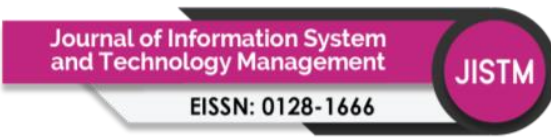

Volume 6 Issue 23 (November 2021) PP. 147-155

DOI: 10.35631/JISTM.623013

Special Issue: Foundation Program Education Post-Covid-19: Issues and Opportunities

Keywords:

Blended Learning, Effectiveness, New Normal, Online Examination, Online

Learning, Pandemic

\section{Introduction}

For the past decades, the teaching and learning process of pre university students was through classroom setting and face to face interaction. Teachers and lecturers used to deliver their lesson face to face lectures, hands on activities, actual experiments, and interactive activities. Meanwhile, students used to ask questions directly to their teachers and lecturers, physically present for examination and any other discussions. However, due to pandemic COVID-19 that leads to a serious health disease in early 2020, all teaching activities are fully forced to utilise to online learning. Even though both parties were being affected because of pandemic situations, but life and education process must go on. The students are affected in terms of educational set-up for online class and examinations. Allen and Seaman (2005) divided courses into four categories; traditional course without online technologies, web-facilitated courses using Learning Management System (LMS), blended/hybrid categories and lastly by no faceto-face meetings. In UMS, we mainly focusing on the second courses which is web-facilitated by smartv3.ums, as well as the online examinations.

Florence et al. (2020) construct four main issues on online learning readiness among student as online students' attributes, time management, communication, and technical issues during online classes. Mohd Salman and Aziah (2012) have discussed that not all students interested to engage or learn in online learning. This finding agreed by Norwati and Zaini (2007). Somehow, all students are adapting slowly with the current situations.

Daniel (2020) mentioned that education system related to curriculums, educators, students, and assessment has changed due to pandemic covid19. In another report by Luthra and Mackenzie (2020), the way to educate our future generations and defining the educator's role has also changed because of the pandemic COVID-19. Concurrently, many efforts have been made by the universities to increase the development of online learning systems. According to Adam et al. (2018), to produce highly creative graduates in future, online learning has become one of the important aspects in our education systems. However, Shukri et al. (2020) found that online synchronous learning is not as effective as traditional classes. Meanwhile, in Philips (2015) mentioned that internet-based education was more likely to be accepted by the students if it offers more advantage over the traditional ways.

Australian vocational education and training sectors by Warner et al. (1998) has proposed the concept of readiness for online learning. Smart \& Cappel (2006) and Aminuddin et al. (2021) mentioning that the online learning term is interchangeable to e-learning, web-based learning, mixed learning as well as virtual learning. Since 1990, online learning has increased with higher education institutions investing considerable resources in electronic learning technologies (Deng \& Tavares (2013); Moore (2013). These technologies included learning management systems (LMS) to help in online courses and online student's collaborations. 
Special Issue: Foundation Program Education Post-Covid-19: Issues and Opportunities Widodo et al. (2020) propose that online learning readiness can be assessed from a few aspects: equipment capability, technology skills, self-directed learning, motivation, and perceived usefulness. This finding agreed on the study made by Anwar et al. (2020), mentioning that the students still need more time to adapt with online learning and need more guidance form their teachers and lecturers. Equipment capability is including computer devices and internet access, proving that these effects the students' readiness very much. Therefore, the purpose of this study is to do a simple assessment on AUMS students to find out on their readiness towards online examination.

\section{Objective of the study}

The objectives of the study are as follows:

1. To study AUMS students' internet connectivity during online classes and their readiness on online examination,

2. To investigate the most preferable platform for the online classes.

\section{Limitation of the study}

This study is conducted only on preuniversity students who enrolled in Foundation in Science program at University Malaysia Sabah (UMS), Kota Kinabalu. Thus, the findings of this survey cannot be generalized to all pre university students in the other university.

\section{Methodology}

\section{Research Design}

This research uses structured questionnaire that was developed based on our objectives. A few questions were tuned to fit in the purpose of the study. The questionnaire is shown in Table 1 below.

Table 1: The Questionnaires Survey

\begin{tabular}{|c|c|c|c|c|c|c|}
\hline No. & Items & \multicolumn{5}{|c|}{ Answer } \\
\hline 1. & Nama & & & & & \\
\hline 2. & Tutorial group & & & & & \\
\hline 3. & Your presence during online class? & & & & & \\
\hline 4. & $\begin{array}{l}\text { Your internet access throughout online } \\
\text { class? }\end{array}$ & & Yes & & No & \\
\hline 5. & $\begin{array}{l}\text { How is your line connectivity throughout } \\
\text { online class? }\end{array}$ & 1 & 2 & 3 & 4 & 5 \\
\hline 6. & $\begin{array}{l}\text { Overall, please rate your experience } \\
\text { during your online class? }\end{array}$ & 1 & 2 & 3 & 4 & 5 \\
\hline 7. & $\begin{array}{l}\text { Which online classes platform do you } \\
\text { prefer? }\end{array}$ & & & & & \\
\hline 8. & $\begin{array}{l}\text { Your readiness to sit for an online } \\
\text { examination? }\end{array}$ & & Ready & & Not re & \\
\hline 9. & If there are any comments, please specify. & & & & & \\
\hline
\end{tabular}

\section{Sample of Study}

The study was conducted on 258 students of Preparatory Centre for Science and Technology (PPST), University Malaysia Sabah, Kota Kinabalu from the intake of 2020/2021. The students Copyright (C) GLOBAL ACADEMIC EXCELLENCE (M) SDN BHD - All rights reserved 
Special Issue: Foundation Program Education Post-Covid-19: Issues and Opportunities were asked to answer questionnaire given through email to gather the information on their internet connectivity in their current locations.

\section{Data Collection}

The students were initially informed on the purpose of this survey. Due to the Movement Control Order (MCO), the survey was conducted online using google forms. The data collection process took about a week to be completed by all the students. Overall, all students responded to the survey.

\section{Data Analysis}

The data collected is then analyzed manually and presented in the form of percentage, mean and standard deviation values. Each item in the survey is analysed to get the basic idea on how the students internet connectivity in their current locations was.

\section{Findings}

The basic information obtained in this study are in terms of their name, current location during online classes and their tutorial groups. Preparatory Centre for Science and Technology (PPST) have grouped all the students into 12 different tutorial groups as shown in Figure 1 below.

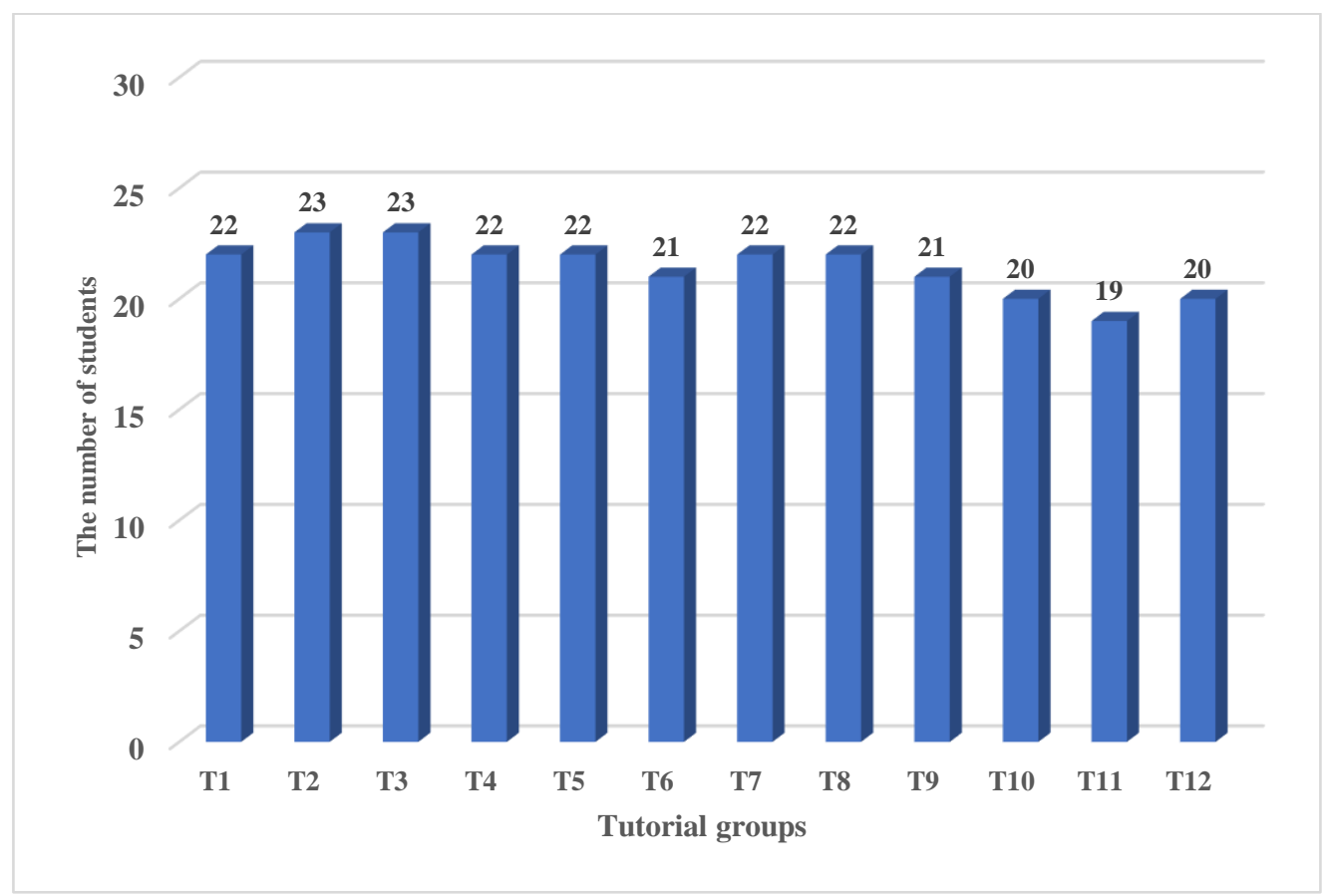

Figure 1: Tutorial Groups of Students

Roughly, 99\% of the students responded that they have internet connectivity in their locations as shown in Figure 2., which means that online class can be done easily. Based on the data obtained, half of the students are still staying inside UMS hostel while the other half staying at their home. According to the data, some of the students did not have a good strength of internet connectivity which affected their online class as well. Based on the students' comments, unstable internet connection is due to rainy day or bad weather in their area. Some of their location indeed having sudden blackout and directly affect the student's internet connectivity. 


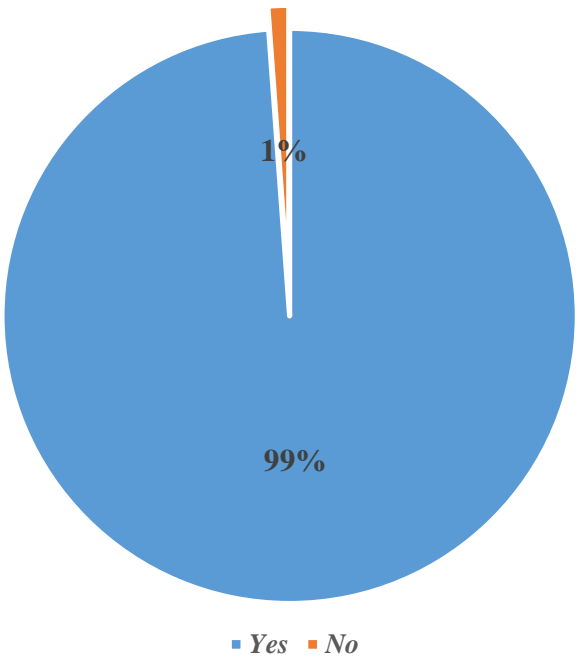

Figure 2. Students' Internet Connectivity

More precisely, Figure 3 shows that the students internet connectivity survey. It is scored from 1-VERY POOR, 2-POOR, 3-MODERATE, 4-GOOD, AND 5-VERY GOOD. The mean obtained for this item is 3.41 and standard deviation of 0.9507 . According to this value, more than $68.2 \%$ of the students have the internet connectivity in their locations. This is mostly contributed by the students who stayed in hostel as UMS provided the students with a good internet accessibility.

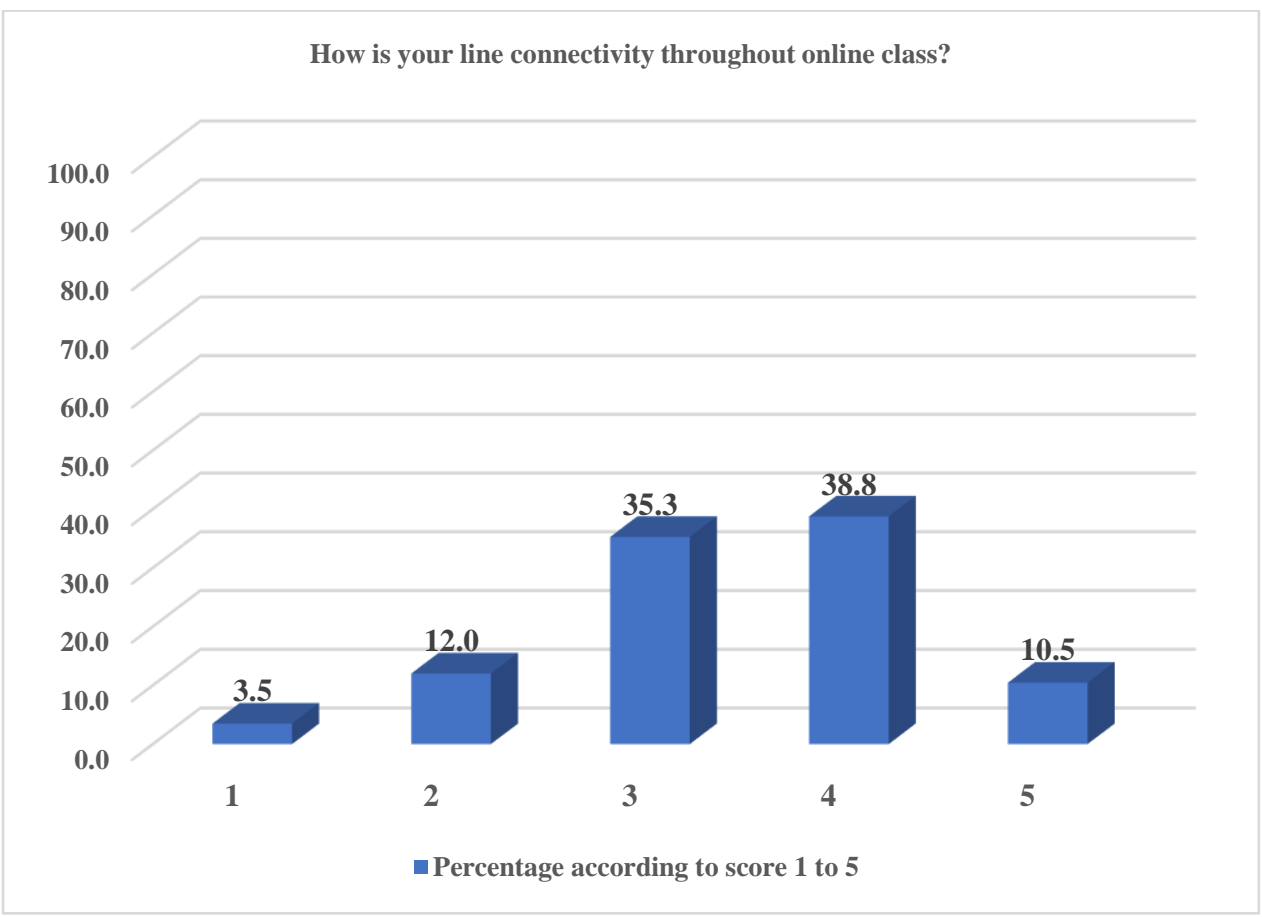

Figure 3. The Graph of Students' Internet Connectivity 
Volume 6 Issue 23 (November 2021) PP. 147-155

DOI: 10.35631/JISTM.623013

Special Issue: Foundation Program Education Post-Covid-19: Issues and Opportunities Based on the students experience during online classes, Figure 4. shows that $44.6 \%$ of the students scored '3-MODERATE' on their online class experiences. Meanwhile, $31.8 \%$ and $8.9 \%$ scored ' 4 ' and ' 5 ' respectively. This means they have a very good and enjoy online class experience.

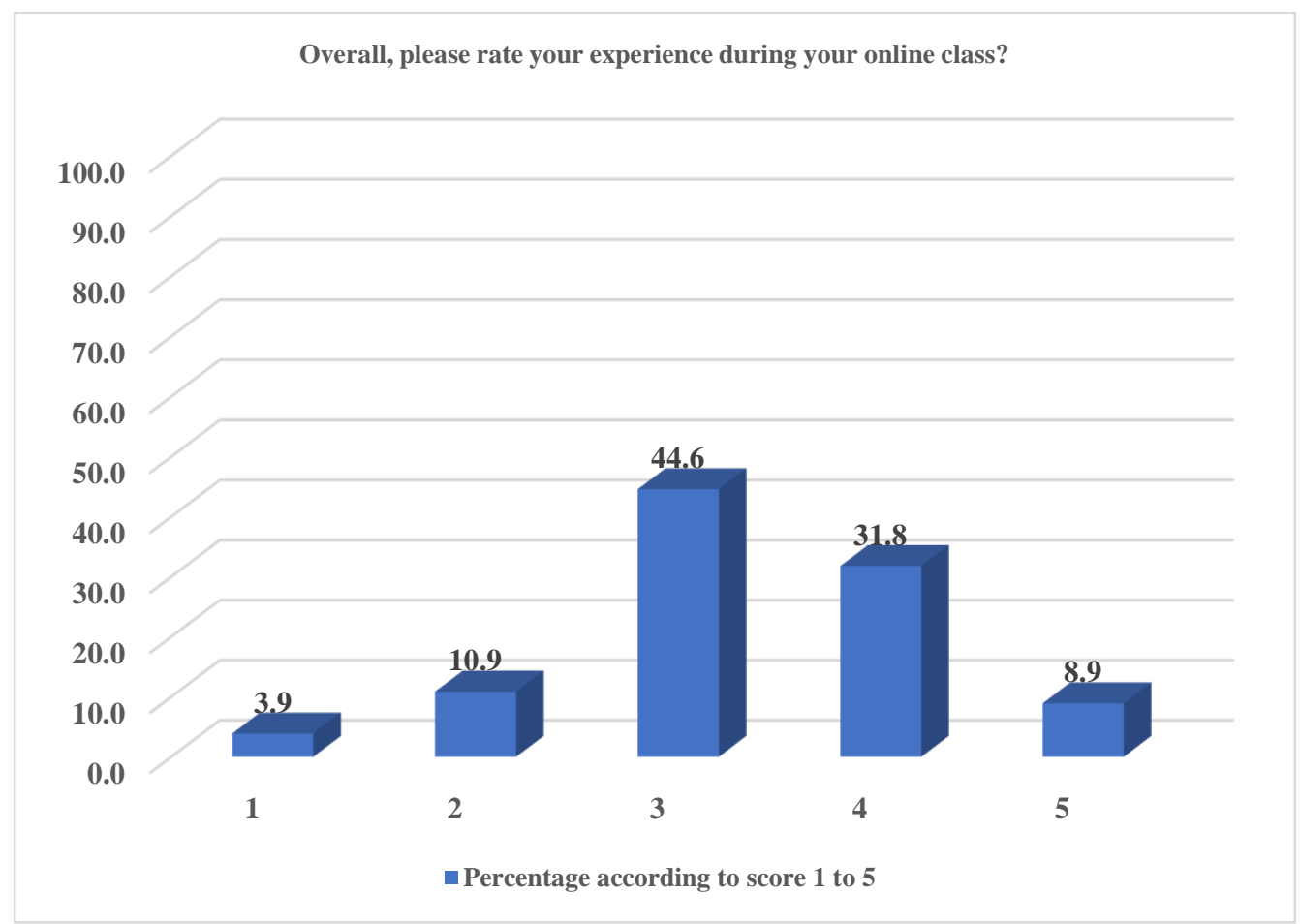

Figure 4. The students' Online Class Experiences

Meanwhile, Figure 5 shows 205 of them contributed to $79.5 \%$ chooses Google meet application as the preferred platform for online class. Based on their comments in the online survey, they believed that Google meet is more flexible, friendly user, as it consumes less memory and data to their handphone/laptop compared to zoom or google classroom applications. 
Special Issue: Foundation Program Education Post-Covid-19: Issues and Opportunities

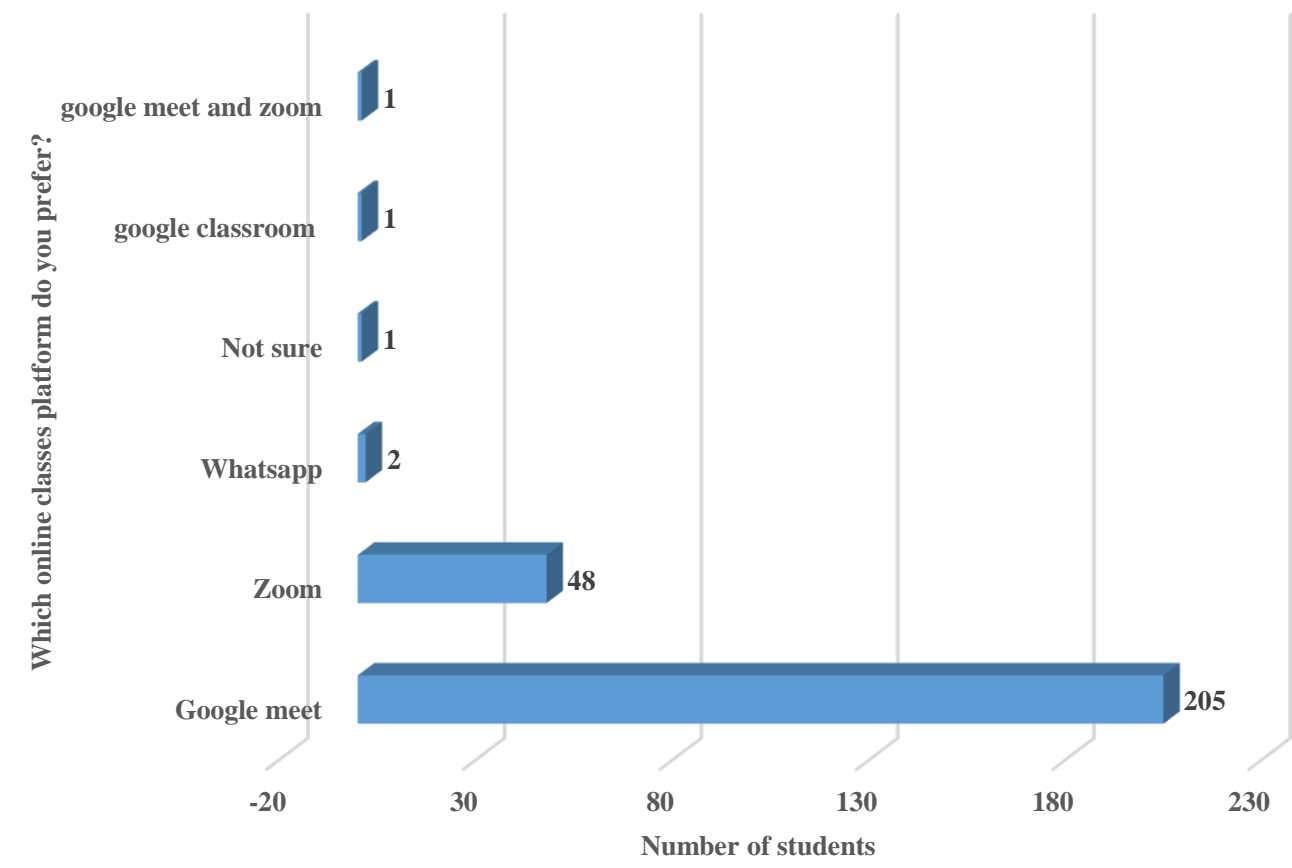

Figure 5. The Most Preferable Platform for Online Classes

Overall, based on pie chart below, $63 \%$ of the students are not ready yet for the online final examination. This is because of their internet connectivity which is sometimes not strong enough especially during raining season. Besides that, their housing area are sometimes having sudden blackout and fully affecting their internet connections.

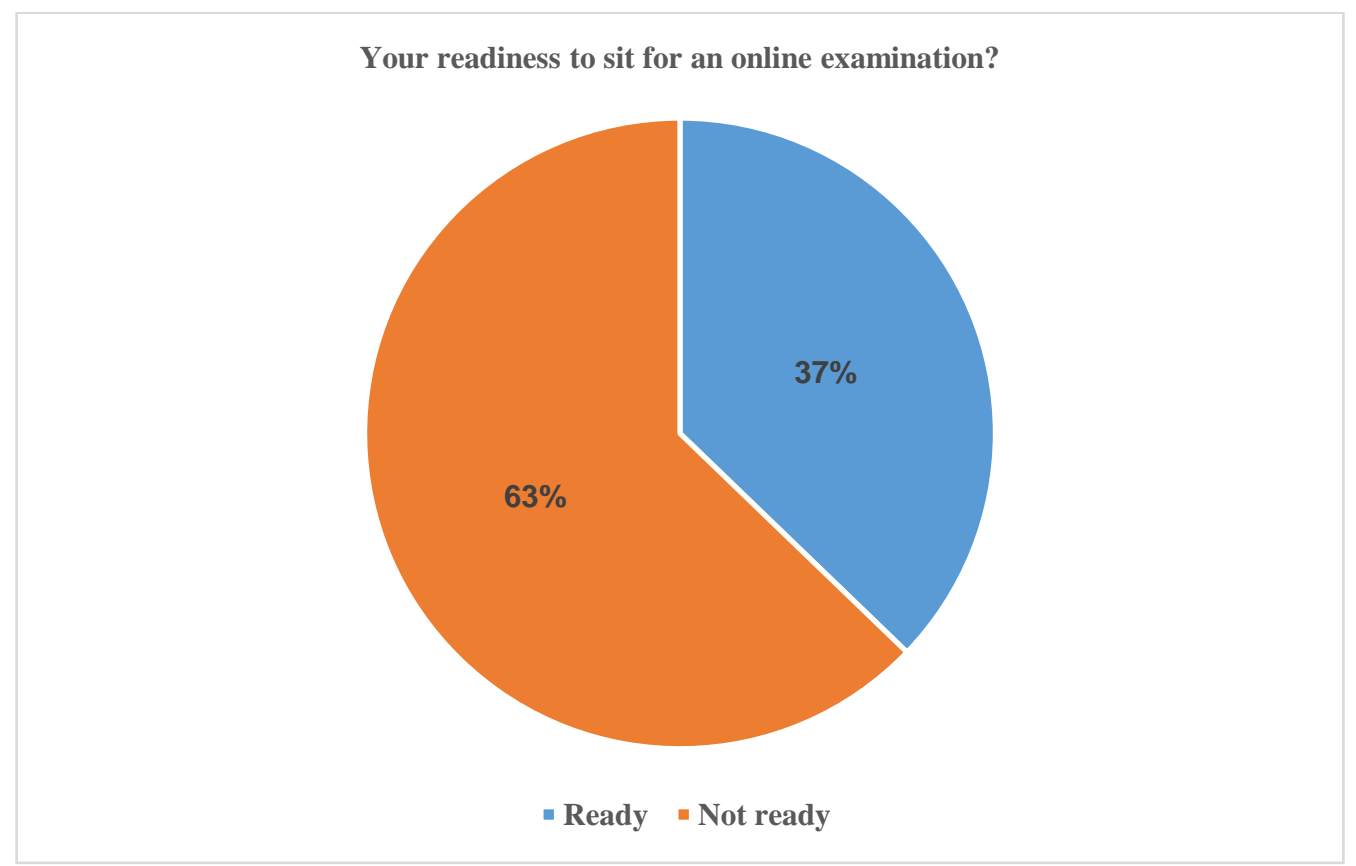

Figure 6. Percentage on Students' Readiness for Their Online Examination. 


\section{Conclusion}

Special Issue: Foundation Program Education Post-Covid-19: Issues and Opportunities

From this survey, it can be concluded that the students' internet connectivity is in average level. If the students are staying in urban area, then their internet connections should be good and vice versa. In additions, these finding is very crucial to know whether the students are ready enough or not. By knowing the level of students' readiness for online examination, lecturers can make full use of it, which is at least by preparing some backup plan for the students who might lost internet connections during the online examination.

\section{References}

Allen and Seaman (2005). Growing by degrees: Online education in the United States, 2005. Needham, M. A.: The Sloan Consortium.

Adams, D., Sumintono, B., Mohamed, A., \& Noor, N. S. M. (2018). E-Learning Readiness Among Students of Diverse Backgrounds in A Leading Malaysian Higher Education Institution. Malaysian Journal of Learning and Instruction, 15(2), 227-256.

Aminuddin, A. S., Azmi, M. N. F., Sulaiman, M. A., \& Saini, N. A. (2021). Readiness for online distance learning (ODL): Understanding the attitudes among students in UITM Pahang. e-Proceedings of International Conference on Language, Education, Humanities \&Social Sciences (i-LEdHS2021)

Anwar, K. I. S., Omar, N., Isa, M. N. S., \& Shamsudin, S. M. (2020). Students' Acceptance and Readiness towards Distrance Learning during COVID-19 Pandemic. International Journal of Education and Pedagogy, 2(4), 39-50.

Daniel, S. J. (2020). Education and the COVID 19 Pandemic. Prospects, 49, 91-96. https://doi.org/10.1007/s11125- 020-09464-3

Deng, L., \& Tavares, N. (2013). From moodle to Facebook: Exploring students' motivation and experiences in online communities. Computers \& Education, 68, 167-176. doi: 10.1016/j.compedu.2013.04.028

Luthra, P., \& Mackenzie, S. (2020). 4 Ways Covid-19 Education Future Generations. https://www.weforum.org/agenda/2020/03/4-ways-covid-19-educationfuturegenerations/

Martin, F., Stamper, B., \& Flowers, C. (2020). Examining student perception of their readiness for online learning: Importance and confidence. Online Learning, 24(2), 38-58. https://doi.org/10.24059/olj.v24i2.2053

Mohd Salman, A. M. \& Aziah, I (2012).Learning Styles and Perception of Engineering Students Towards Online Learning. Procedia - Social and Behavioral Sciences, 69(Iceepsy), 669-674. https://doi.org/10.1016/j.sbspro.2012.11.45

Moore, M. G. (2013). Handbook of distance education (3rd Edition) Routledge SFA Widodo et al. (2020) J. Phys.: Conf. Ser. 1700012033

Norwati, MD. Y. \& Zaini, A. 2007. Analisi Deskriptif e-forum dalam Pembelajaran KursusTerjemahan di Universiti Kebangsaan Malaysia. GEMA Online Journal of Language Studies. 7(2). pp79-93.

Phillips, J. A. (2015). Replacing traditional live lectures with online learning modules: Effects on learning and student perceptions. Currents in Pharmacy Teaching and Learning, 7(6), 738-744. https://doi.org/10.1016/j.cptl.2015.08.009

Smart, K. L., \& Cappel, J. J. (2006). Students' perceptions of online learning: A comparative study. Journal of Information Technology Education, 5, 201-219.

Shukri, A., Nordin, L., Salleh, F. I. M., Radizwan, S. N. M. \& Ahmad, R. (2020) UniKL Students' Perception On Synchronous Learning Using Ict As Learning Tools To Learn 
Volume 6 Issue 23 (November 2021) PP. 147-155

DOI: 10.35631/JISTM.623013

Special Issue: Foundation Program Education Post-Covid-19: Issues and Opportunities English, Journal of Critical Reviews, Vol 7 (8), 793-796. Doi: http://dx.doi.org/10.31838/jcr.07.08.170

Warner, D., Christie, G., \& Choy, S. (1998). Readiness of VET clients for flexible delivery including on-line learning. Brisbane: Australian National Training Authority. 